\title{
FIRST RECORD OF THE LONG-TAILED DUCK FOR COAHUILA, MEXICO
}

\author{
HUGO GONZÁLEZ-PÁEZ, Laboratorio de Ornitología, Facultad de Ciencias \\ Biológicas, Universidad Autónoma de Nuevo León, San Nicolás de Los Garza, \\ Nuevo León, 66451, México; hugo.gzz.paez@gmail.com
}

ARMANDO J. CONTRERAS-BALDERAS, Cerro de la Conformidad 115, Las Puentes, Sector 2, C.P. 66460, San Nicolás de los Garza, Nuevo León, México; ajcb1951@gmail.com

GORGONIO RUIZ-CAMPOS, Colección Ornitológica, Facultad de Ciencias, Universidad Autónoma de Baja California, Carretera Transpeninsular EnsenadaTijuana No. 3917, Colonia Playitas, C.P. 22860, Ensenada, Baja California, México; U.S. mailing address: PMB 064, P.O. Box 189003, Coronado, California 92178; gruiz@uabc.edu.mx

JUAN A. GARCÍA-SALAS, Laboratorio de Ornitología, Facultad de Ciencias Biológicas, Universidad Autónoma de Nuevo León, San Nicolás de Los Garza, Nuevo León, 66451, México

The Long-tailed Duck (Clangula hyemalis) is a distinctive sea duck that breeds on high arctic coasts and tundra of both the eastern and western hemispheres. In North America, it winters south along the Pacific coast to California and along the Atlantic coast to northern Florida. In the interior of the continent, it winters regularly in large numbers on the Great Lakes (AOU 1998, Robertson and Savard 2002). The species occurs in migration or winter in all states of the continental U.S., including south to the Gulf of Mexico from Florida to Texas, and across the interior of the border states of Texas, New Mexico, Arizona, and California, where rare but annual in occurrence (AOU 1998, https://eBird.org).

The Long-tailed Duck was historically known in Mexico only from coastal areas in the northwest, primarily in the Gulf of California, where first reported in 1926 (Huey 1927). In the gulf it was historically rare, but records extend south to Sinaloa and Jalisco (Howell and Webb 1995); Mexico's first and still only specimen (an unsexed juvenile, number 4777 deposited in Humboldt State University Museum, Arcata, California) was collected on 27 December 1979, $15 \mathrm{~km}$ southwest of Guamúchil, Sinaloa (Kramer 1982). Russell and Monson (1998) and Erickson et al. (2001) added four additional records for the states of Sonora and Baja California through the 1990s, and Erickson et al. (2013) added a record from Bahía de los Angeles, Baja California, in 2006. Over the past two decades, however, reports have increased considerably in that region; since 2000, there have been at least 14 records along both coasts of the Baja California Peninsula south to Loreto, where photographed 24-28 December 2017 (https://ebird.org/checklist/S41326540), representing the first well-supported record for Baja California Sur. Furthermore, seven records in eBird since the 1990s in coastal Sonora south to Bahia Santa Rosa, Isla Tiburón (Rojas-Soto et al. 2002) include observations of groups of up to six birds (at Golfo Santa Clara; https://ebird.org/checklist/S82628948).

During field work in northern Coahuila on 23 November 2013, we photographed a winter-plumaged female Long-tailed Duck (Figure 1). The site $\left(28^{\circ} 05^{\prime} 02.3^{\prime \prime} \mathrm{N}\right.$, $101^{\circ} 37^{\prime} 45.9^{\prime \prime} \mathrm{W}$, elevation $505 \mathrm{~m}$ ) was a small pluvial lake (45 m long and $13 \mathrm{~m}$ wide) located along state highway 20,25 km north-northwest of the town of Melchor Múzquiz. The duck was initially seen feeding close to shore, but as we approached it swam out to the center of the puddle. Other waterbirds there were two Redheads (Aythya americana) and a Pied-billed Grebe (Podilymbus podiceps). The previous records of the Long-tailed Duck nearest our sighting are of single individuals 


\section{NOTES}

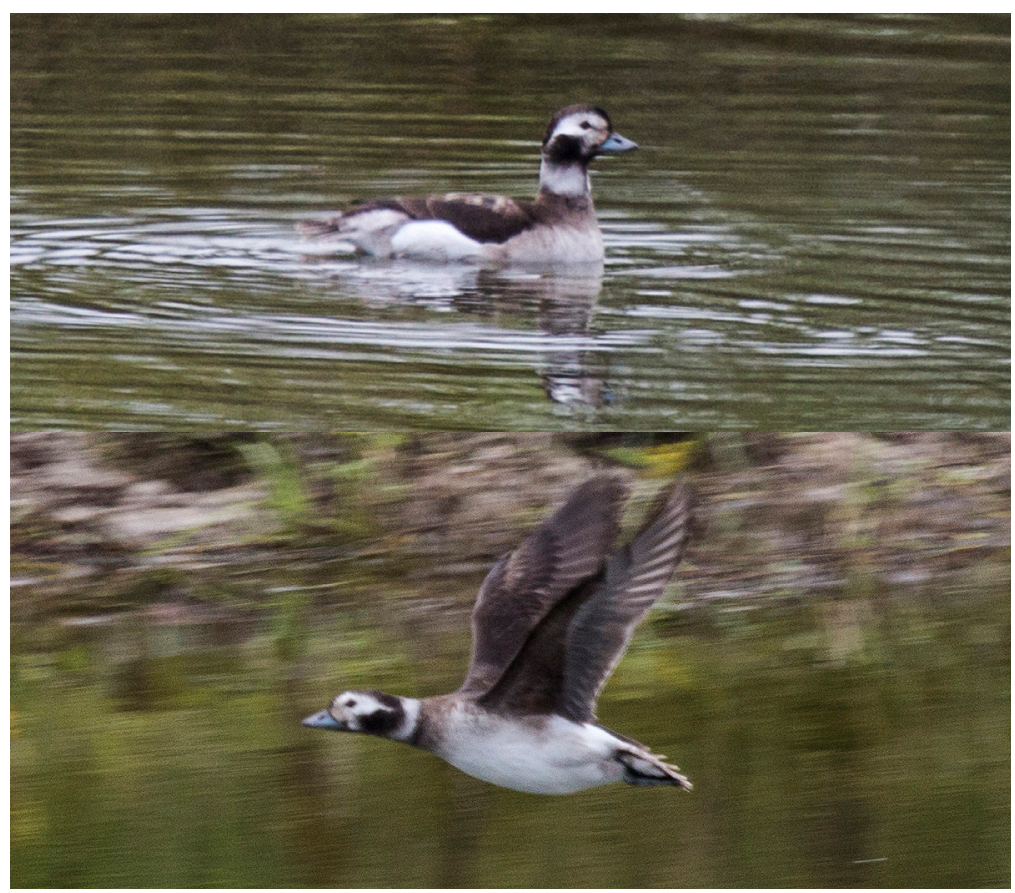

Figure 1. Long-tailed Duck $25 \mathrm{~km}$ north-northwest of Melchor Múzquiz, Coahuila, México, 23 November 2013

Photos by Hugo González-Páez

photographed in the Rio Grande valley at Laredo, Texas, 17 December 2016 (https:// ebird.org/checklist/S33057392) and in the trans-Pecos region of Texas at Marathon 7 December 2013 (https://ebird.org/checklist/S15883753). Also, according to the records taken from eBird, from 1972 to 9 August 2021, there were 11,260 observations of the species between the USA and Mexico; all of those between latitudes of $26^{\circ}$ and $31^{\circ} \mathrm{N}$ represent occurrences during fall migration and winter. Mexico and Texas together account for 2633 sightings; of these, 567 are from Mexico and the border counties of Texas. Therefore, we consider that our record does not represent a vagrant or accidental; more field studies are required in order to define the regularity of this species in Mexico.

To the best of our knowledge, this constitutes the first record of the Long-tailed Duck for the state of Coahuila. In addition, it appears to be the first record for anywhere in interior Mexico and the easternmost record for the country and the first located in the Atlantic drainage.

We thank reviewers Mark Lockwood and especially Sartor O. Williams III for their corrections and useful suggestions for the manuscript.

\section{LITERATURE CITED}

American Ornithologists' Union. 1998. Check-list of North American Birds, $7^{\text {th }}$ ed. Am. Ornithol. Union, Washington, D. C. 


\section{NOTES}

Erickson, R. A., Hamilton, R. A., and Howell, S. N. G. 2001. New information on migrant birds in northern and central portions of Baja California Peninsula, including species new to México, in Birds of the Baja California Peninsula: Status, Distribution and Taxonomy (R. A. Erickson and S. N. G. Howell, eds.), pp. 112-170. Am. Birding Assoc. Monog. Field Ornithol. 3.

Erickson, R. A., Carmona, R., Ruiz-Campos, G., Iliff, M. J., and Billings, M. J. 2013. Annotated checklist of the birds of Baja California and Baja California Sur, second edition. N. Am. Birds 66:582-613.

Howell, S. N. G., and Webb, S. 1995. A Guide to the Birds of Mexico and Northern Central America. Oxford Univ. Press, Oxford, England.

Huey, L. M. 1927. Birds recorded in spring at San Felipe, northeastern Lower California, Mexico, with the description of a new woodpecker from that locality. Trans. San Diego Soc. Nat. Hist. 5:13-42.

Kramer, G. W. 1982. Oldsquaw record from Sinaloa, Mexico. Condor 84:243; https:// doi.org/10.2307/1367683.

Robertson, G. J., and Savard, J. P. L. 2002. Long-tailed Duck (Clangula hyemalis), in The Birds of North America (A. Poole and F. Gill, eds.), no. 651. Birds N. Am., Inc., Philadelphia; https://doi.org/10.2173/bow.lotduc.01.

Rojas-Soto, O. R., Puebla Olivares, F., Figueroa-Esquivel, E. M., Sánchez-González, L. A., Nakazawa-Ueji, Y. J., Ríos-Muñoz, C. A., and Navarro-S., A. G. 2002. Avifauna de Isla Tiburón, Sonora, México. Anal. Inst. Biol., Ser. Zool., 73:73-89.

Russell, S. M., and Monson, G. 1998. The Birds of Sonora. Univ. of Ariz. Press, Tucson. 